\title{
The Effect of Boric Acid on Corrosion of SS 304 as PWR Pressurizer Material
}

\section{Febrianto}

Center for Nuclear Reactor Safety and Technology National Nuclear Energy Agency of Indonesia (BATAN) Puspiptek Complex, Building No. 80, PUSPIPTEK area, Serpong, Tangerang 15310, Indonesia

\section{Abstract}

The pressurizer is the component in the reactor coolant system which provides a means of controlling the system pressure. The pressurizer has a function to keep the operational pressure of reactor coolant system in set point condition. For controlling primary coolant system pressure, the pressurizer has pressurizer spray, heater, safety relief valve and instrumentation to control level and pressurizer. The purpose of this study is to see the effect of boric acid, lithium hydroxide and temperature on SS 304 as PWR pressurizer material. The method that used in this research is to observe the

Corresponding Author:

Febrianto; email:

febrianto_bahar@yahoo.com

Received: 29 July 2016

Accepted: 21 August 2016

Publishing: 21 September 2016

\section{Publishing services}

provided by Knowledge E

Febrianto. This article is distributed under the terms of the Creative Commons Attribution License, which permits unrestricted use and redistribution provided that the original author and source are credited.

Selection and Peer-review under the responsibility of the ICONETS Conference Committee.

\section{S OPEN ACCESS} corrosion rates of pressurizer material in several boric acid and lithium hydroxide concentration at several temperature conditions using Potentiostat. Tests were conducted in $28,60,80$, and $100{ }^{\circ} \mathrm{C}$ in $2000,2500,3000$ ppm boric acid and addition 2.0 and $2.5 \mathrm{ppm}$ lithium hydroxide. The pressurizer material corrodes in solution containing boric acid solution. The corrosion rates increased if boric acid solution concentration and temperature also increased. The results showed that that corrosion rate for the material were very small and the highest corrosion rate occurred in 3000 ppm boric acid concentration at $80^{\circ} \mathrm{C}$, that is $4.5913 \times 10^{-1} \mathrm{mpy}$. The corrosion rates increased until temperature $80{ }^{\circ} \mathrm{C}$, but increasing the temperature from $80^{\circ} \mathrm{C}$ to 100 ${ }^{\circ} \mathrm{C}$ decreased the corrosion rates from $4.5913 \times 10^{-1}$ to $4.5264 \times 10^{-1} \mathrm{mpy}$. Lithium hidroxide addition in boric acid containing media generally decreased SS 304 corrosion rate as $\mathrm{P}$ W R pressurizer material. $\mathrm{K}$.

Keywords: pressurizer, primary coolant system, boric acid, lithium hydroxide, corrosion rate

\section{Introduction}

The pressurizer is the component in the reactor coolant system which provides a means of controlling the system pressure. The pressurizer has a function to keep the operational pressure of reactor coolant system in set point condition. The pressurizer surge line is connected to one of the reactor coolant hot legs and the spray lines are connected to two of the cold legs at the reactor coolant pump discharge. Pressurizer maintains the steam's and water'spressure are kept in thermal equilibrium. Chemical and Volume Control System controls thewater level and quality. 
SA -533 GR-B-CL-1 or SA-508 Grade 3, Class 1 as Vessel Base material which coated SS 304 or Ni-Cr-Fe Steel used as pressurizer vessel material. The chemical composition and mechanical properties from pressure vessel material can be seen in Table 1. This research was conducted based on consideration many corrosion problems occurred in several PWR primary coolant system components such as; steam generator tube, as well as reactor vessel head [1-5]. The chemical composition and mechanical properties are listed in Table 1.

\begin{tabular}{|c|c|c|c|c|}
\hline ASME spec & \multicolumn{2}{|c|}{ SA-533 } & SA-508 & SS-304 \\
\hline Type or grade & \multicolumn{2}{|c|}{ Type B } & Gr. 2 & \\
\hline Class & 1 & 2 & 1 & \\
\hline$C(\%)$ & $\leq 0.25$ & $\leq 0.25$ & $\leq 0.35$ & $\leq 0.060$ \\
\hline Si & $0.15-0.40$ & $0.15-0.40$ & $0.15-0.35$ & 0.59 \\
\hline $\mathrm{Mn}$ & $1.15-1.50$ & $1.15-1.50$ & $0.40-0.90$ & 1.69 \\
\hline$P$ & $\leq 0.035$ & $\leq 0.035$ & $\leq 0.025$ & $\leq 0.024$ \\
\hline$S$ & $\leq 0.04$ & $\leq 0.04$ & $\leq 0.025$ & $\leq 0.013$ \\
\hline $\mathrm{Ni}$ & $0.40-0.70$ & $0.40-0.70$ & $\leq 0.4$ & 8.88 \\
\hline $\mathrm{Cr}$ & - & - & $\leq 0.25$ & 18.33 \\
\hline Mo & $0.45-0.60$ & $0.45-0.60$ & $\leq 0.1$ & 0.14 \\
\hline v & - & - & $\leq 0.05$ & \\
\hline
\end{tabular}

TABLE 1. Chemical composition and Mechanical Properties [1].

In $\mathrm{PWR}, \mathrm{H}_{3} \mathrm{BO}_{3}$ and $\mathrm{LiOH}$ combination is used for $\mathrm{pH}$ controlling. At the beginning the fuel cycle, maximum lithium concentration is $2.2 \mathrm{ppm}$. If lithium concentration higher than $2.2 \mathrm{ppm}$ it will initiate fuel cladding corrosion. PWR reactor is recommended to be operated in range $\mathrm{pH} 6.9-7.4$, with boric acid concentration around $1800-3000$ ppm and lithium hydroxide concentration around $2.2-3.5$ ppm. This range of $\mathrm{pH}$ is necessary to control the corrosion of primary system materials and also to minimize corrosion product transport within the primary system. The lithium concentration normally decreases according to decreasing boric acid concentration and is reduced to $~ 0.6 \mathrm{ppm}$ at the end of a fuel cycle. At several US PWR reactor has found damage cause of boric acid corrosion/BAC) [1]. Boric acid addition has a negative effect to reactor primary coolant system component. Boron added in reactor coolant system in boric acid form $\left(\mathrm{H}_{3} \mathrm{BO}_{3}\right)$ via Control Volume Chemical System (CVCS)

At US PWR reactor, David Besse, three CRDM nozzles had indications of axial cracking, which had resulted in leakage of the reactor's pressure boundary. This crack had resulted in leakage reactor primary water coolant. At March, 2002, during VHP inspection, cavity was found at David Besse Reactor Pressure vessel Head adjacent to control-rod drive mechanism. These cavities caused by boric acid corrosion attack, many efforts have been under way to understand the mechanisms of BAC [6-8]. To 
prevent boric acid corrosion on reactor material is necessary to reduce the leakage of reactor coolant water.

\section{Theory}

Boron addition to PWR reactor coolant has purpose to control reactor reactivity mainly during reactor start-up. Boron as boric acid $\left(\mathrm{H}_{3} \mathrm{BO}_{3}\right)$ combination with lithium hydroxide (LiOH) has a role to control pH of reactor primary coolant. Many PWR reactor are operated in range $\mathrm{pH} 6.9$ to 7.4 during fuel cycle [1-5,9-10]. PWR primary chemistry control aims to maintain primary system pressure boundary and fuelcladding integrity, to provide for reactivity control, and to minimize ex-core radiation fields. Primary chemistry control is optimized to insure that the fuel and pressure boundary components integrity objectives are achieved. Operation at elevated $\mathrm{pH}$ can reduce ex-core radiation fields but the accompanying elevated lithium concentrations can lead to an increased likelihood of stainless steel corrosion, at a lower operating lithium concentration, the likelihood of stainless steel integrity problems will be minimized but an increased buildup rate of radiation fields may result. The major focus of primary chemistry programs today is $\mathrm{pH}$ control. Specifically, operation below pH6.9 is not desirable because of the expected more material corrosion effect will occur. At the present time, almost all plants are operating at $\mathrm{pH}$ (tave) $=6.9$ or above. Recently, several plants operating with localized boiling in some parts of the core have experienced an axial offset anomaly (AOA), which hasbeen attributed of high concentration of lithium and boron. AOA anomaly occurs cause of lithium boron compounds deposits at fuel surface. To solve this problem, many plant in Germany apply enrich boric acid for reducing boron in reactor coolant and reduce lithium concentration addition.

\section{Methodology}

SS 304 was used as specimen in this experiment. The specimen surface was polished with alumina powder. This report presents experimental data on corrosion rates of the SS 304 materials as PWR pressurizer material in boric acid, boric acid + lithium hydroxide solutions in varying concentrations and temperatures. Anodic polarization was obtained by a potential scanning from $-500 \mathrm{mV}$ at an open circuit potential(OCP) to $600 \mathrm{mV}$. OCP at a rate of $0.2 \mathrm{mV} / \mathrm{sec}$ after an initial delay of 30 minutes at -200 $\mathrm{mV}$. A Silver/Silver chloride $(\mathrm{Ag} / \mathrm{AgCl})$ and $\mathrm{Pt}$ wire were used as reference electrode and a counter electrode respectively. For each condition, the boron and lithium hydroxide concentrations and temperature were changed to simulate the corrosion effect to SS 304 material. Acccording to the purpose of this ressearch is to get related document which connected to PWR pressurizer material analysis and material corrosion evaluation. Achieving the above purpose, the experiment were performed with several steps:

- Specimen preparation 
- PWR pressurizer material cooosion test use Potentiostat. The found data by Potentiostat is in corrosion current. This data will be calculated using Excel to get corrosion rate data.

- Analysis and report.

\section{Result and Discussion}

Corrosion rate test conducted in several boric acid cooncentrations and boric acid and lithium hidroxide mixture at several temperature variation using Potentiostat. There are three steps in this research, first for corrosion testing, seconds for data analysis corrosion testing, and third for reporting.

\section{Effect of Boric acid addition and temperature on SS 304 Corrosion}

Fig.1 shows experiment results that the increasing temperature tends to increase SS 304 corrosion rate as PWR pressurizer material eventhough is not so significant. SS 304 corrosion rate in $2000 \mathrm{ppm}$ boric acid cotaining solution at $28^{\circ} \mathrm{C}$ is $1.2293 \times 10^{-2}$ mpy and corrosion rate increase to be $3.2937 \times 10^{-2} \mathrm{mpy}$ and $3.8859 \times 10^{-2} \mathrm{mpy}$ at temperature $80{ }^{\circ} \mathrm{C}$, but SS corrosion rate decrease to $3.8859 \times 10^{-2} \mathrm{mpy}$ at temperature $100{ }^{\circ} \mathrm{C}$. SS 304 corrosion rate decreased from $3.8859 \times 10^{-2} \mathrm{mpy}$ at temperature $80^{\circ} \mathrm{C}$ to $3.0603 \times 10^{-2} \mathrm{mpy}$ at $100{ }^{\circ} \mathrm{C}$. Corrosion rate decreasing cause by increasing temperature 80 to $100{ }^{\circ} \mathrm{C}$ will decrease soluble oxygen concentration in solution. Decreasing SS 304 corrosion rate from $3.8859 \times 10^{-2} \mathrm{mpy}$ at temperatur $80^{\circ} \mathrm{C}$ to $3.0603 \times 10^{-2} \mathrm{mpy}$ at $100^{\circ} \mathrm{C}$ caused by increasing temperature from 80 to $100{ }^{\circ} \mathrm{C}$ tend to reduce soluble oxygen concentration in solution. Boric acid addition to 2500 and 3000 ppm has the same effect to boric acid 2000 ppm in SS 304 corrosion rate tendency.

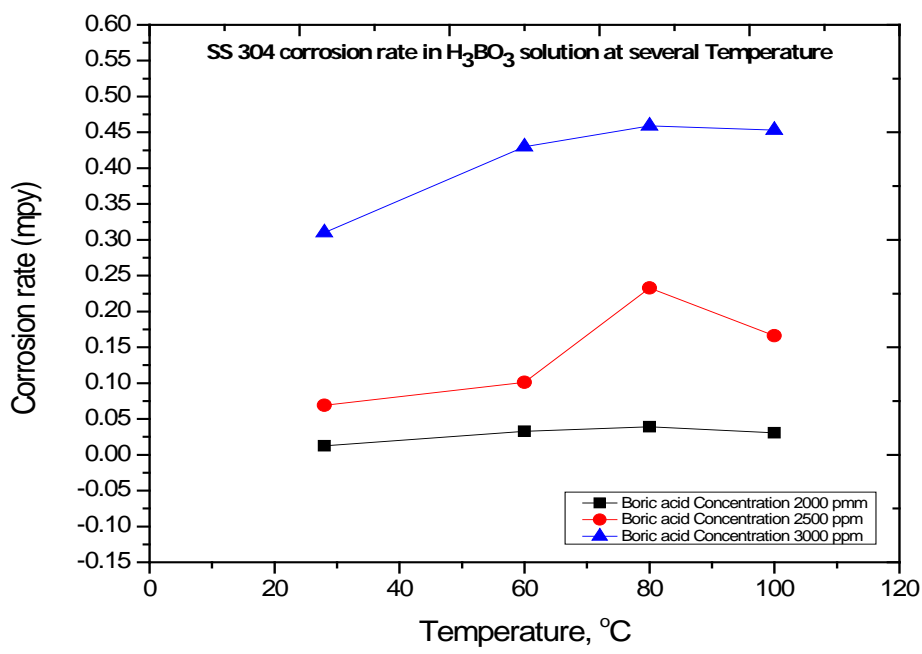

Figure 1. SS 304 corrosion rate in $\mathrm{H}_{3} \mathrm{BO}_{3}$ solution at several temperature. 
6. Effect of $\mathrm{H}_{3} \mathrm{BO}_{3}$ and LiOH addition on SS 304

Corrosion at $80^{\circ} \mathrm{C}$

Fig. 2 shows SS 304 corrosion rate in boric acid at $80{ }^{\circ} \mathrm{C}$ decreased after lithium hydroxide addition

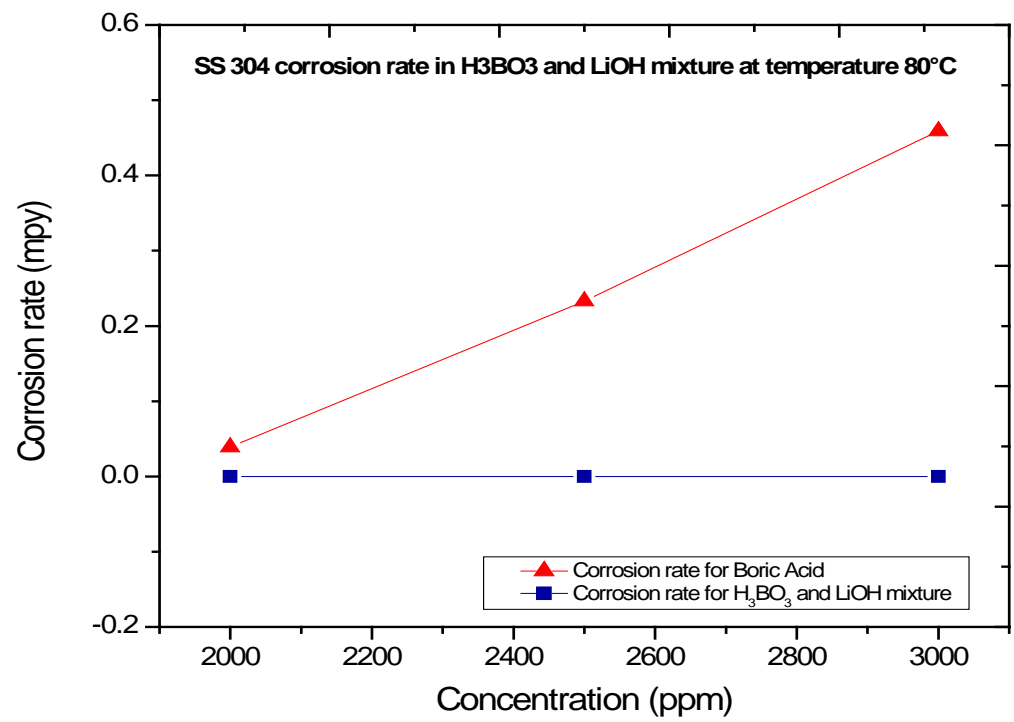

Figure 2. SS 304 corrosion rate in $\mathrm{H}_{3} \mathrm{BO}_{3}$ and $\mathrm{LiOH}$ mixture at $80^{\circ} \mathrm{C}$.

\section{Effect of $\mathrm{H}_{3} \mathrm{BO}_{3}$ and LiOH addition on SS 304}

Corrosion at temperatur $100^{\circ} \mathrm{C}$

Comparing corrosion rates data at temperature $100{ }^{\circ} \mathrm{C}$ (Fig.3) with corrosion data at temperature $80^{\circ} \mathrm{C}$ (Fig. 2) shows that $\mathrm{SS} 304$ corrosion rate in boric acid and boric acid + lithium hydroxide solution tend to decrease cause of increasing temperature from $80{ }^{\circ} \mathrm{C}$ to $100^{\circ} \mathrm{C}$.

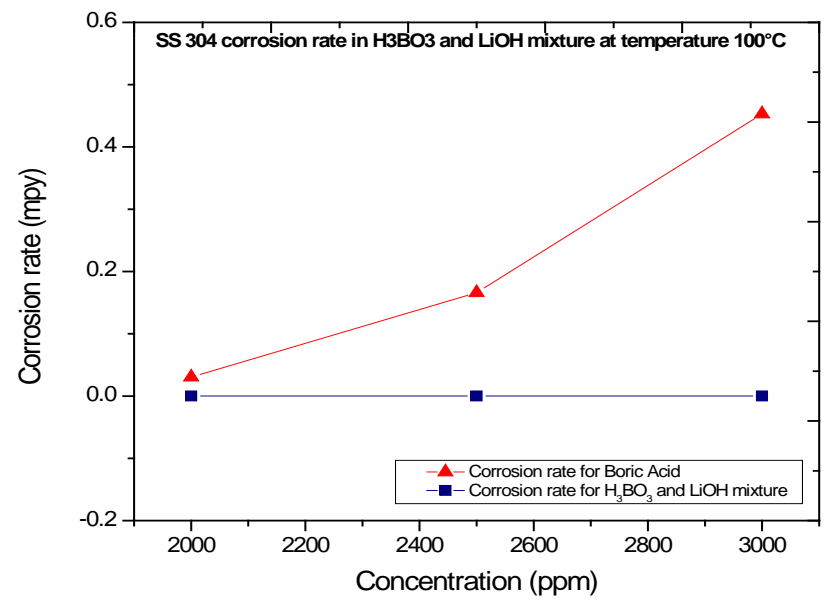

Figure 3. SS 304 corrosion rate in $\mathrm{H}_{3} \mathrm{BO}_{3}$ and $\mathrm{LiOH}$ mixture at $100{ }^{\circ} \mathrm{C}$ 


\section{Conclusion}

The research was conducted at temperature $28,60,80$, and $100{ }^{\circ} \mathrm{C}$ in 2000,2500 and 3000 ppm boric acid concentration with 2.0 and 2.5 ppm lithium hydroxide concntration. From test result data shows SS 304 corrosion rate is relative small and the highest corrosion rate occur in $3000 \mathrm{ppm}$ boric acid concentration at temperature $80{ }^{\circ} \mathrm{C}$, namely $4.5913 \times 10^{-1} \mathrm{mpy}$. Increasing temperature from $80{ }^{\circ} \mathrm{C}$ menjadi $100{ }^{\circ} \mathrm{C}$ decreased SS 304 corrosion rate from $4.5913 \times 10^{-1}$ to $4.5264 \times 10^{-1} \mathrm{mpy}$. Lithium hydroxide addition to boric acid containing solution generally decreased SS 304 corrosion rate as $\mathrm{P} W \mathrm{R}$ pressurizer material. The corrosion experiments in solution containing $\mathrm{H}_{3} \mathrm{BO}_{3}$ and $\mathrm{LiOH}$ showed that the corrosion rates decreased with increasing temperature.

\section{References}

[1] A. L. Stepanov, Rev. Adv. Mater. Sci. 30 (2012) 150-165.

[2] A. A. Youssef ${ }^{a}$, P. Budzynski ${ }^{b}$, J. Filiks ${ }^{c}$, A. P. Kobzev' ${ }^{d}$, J. Sielanko ${ }^{c}$, Vacuum, Vol. 77, Issue 1 (2004) P. 37-45.

[3] N. Kumar, S. Kataria, S. Dash, S. K. Srivastava, C. R. Das, P. Chandramohan, A. K. Tyagi, K. G. M. Nair, Baldev Raj, Wear, Volumes 274-275, 27 January 2012, Pages 60-67.

[4] D. P. Hickey, Diss, University of Florida (2007).

[5] A. Yu. Didyk, R. Wiśniewski, K. Kitowski, V. Kulikauskas, T. Wilczynska, A. A. Shiryaev, Ya. V. Zubavichus, Depth concentrations of deuterium ions implanted into some pure metals and alloys.

[6] P. J. Evans, J. Hyvarinen, M. Samandi, Surface and Coating Technology 71 (1995) 151-158.

[7] K. Feng, X. Cai, Z. Li, P. K. Chu, Mat. Letters 68 (2012) 450-452.

[8] G. Jatisukamto, V. Malau, M. N. Ilman, P. T. Iswanto, J. Ilmiah Teknik Mesin CakraM, Vol.5, No.1 (2011) 14-19.

[9] Effendi, N., Urania, 16(2), 2010.

[10] A. Sujatno, R. Salam, B. Bandriyana, A. Dimyati, Studi Scanning Electron Microscopy (SEM) untuk Karakterisasi Proses Oxidasi Paduan Zirkonium, Seminar Nasional X, SDM Teknologi Nuklir (2014).

[11] M. Vigen Karimi, S. K. Sinha, D. C. Kothari, A. K. Khanna, A. K. Tyagi, Surface and Coatings Techology 158-159 (2004) 609-614. 